\title{
Clinical manifestations in the oral cavity in patients with hyper-IgE syndrome
}

\author{
DOROTA OLCZAK-KOWALCZYK ${ }^{1}$, ANNA MATOSEK', EDYTA HEROPOLITAŃSKA-PLISZKA \\ EWA BERNATOWSKA ${ }^{3}$
}

${ }^{1}$ Department of Paediatric Dentistry, Medical University of Warsaw, Poland

${ }^{2}$ Department of Oral Pathology, The Children's Memorial Health Institute, Warsaw, Poland

${ }^{3}$ Department of Immunology, The Children's Memorial Health Institute, Warsaw, Poland

\begin{abstract}
Introduction: Hyper-IgE syndrome is a rare an autosomal recessive or dominant manner due to gene mutations. This syndrome, from mutations in the STAT3 gene, is characterized by elevated levels of $\mathrm{IgE}>2000 \mathrm{IU} / \mathrm{ml}$, eczema, skin abscesses, recurrent respiratory infections, skeletal abnormalities, oral mucosal lesions, impaired eruption of permanent teeth and root resorption of deciduous teeth.

Aim of the study: Determine phenotypic characteristics of hyper-IgE syndrome in the oral cavity with regard to a modifying impact of environmental factors.

Results: Examination of the oral mucosa revealed white lichenoid lesions, atrophy of the lingual papillae, median schistoglossia, palatine fibrosis, erosions, ulceration and scarring, angular cheilitis. Candida albicans was identified, despite antimycotic treatment. Dental examination revealed caries, unerupted teeth, persistent deciduous teeth, and tooth wear. The phenotypic variability in the oral cavity might have been due to environmental factors.

Conclusions: Although the genetic causes of hyper-IgE have been identified, the pathogenesis of oral lesions in those patients remains to be clarified. The current knowledge allows associating the oral mucosal lesions, i.e., fungus infections, hyperkeratosis and fibrosis, with the STAT3 gene mutation. It also helps to consider its role in odontogenic disorders, particularly in inhibiting eruption of permanent teeth and root resorption in deciduous dentition.
\end{abstract}

Key words: hyper-IgE syndrome (HIES), oral mucosal lesions, candidosis, dental abnormalities, impaired eruption of teeth.

(Centr Eur J Immunol 2013; 38 (1): 92-99)

\section{Introduction}

The hyper-IgE syndrome, described for the first time by Davis et al. in 1966, is a primary immunodeficiency disorder inherited in an autosomal recessive (AR) or dominant (AD) manner. It is a rare condition; girls and boys are equally affected [1]. In the majority of cases, the inheritance is autosomal dominant (AD HIES). In some cases, AD HIES, with a predominant pulmonary manifestation, is due to the STAT 3 gene (Signal Transducer and Activator of Transcription) [2].

Studies into cytokine responses in the two HIES types demonstrated that severely disturbed signal transduction for multiple cytokines, also interleukin 6 and interleukin 23, impairs the function of T-helper type 17. Therefore, HIES may be induced by multiple defective cytokine signals. Hence, the T-helper type 17 defect in individuals with HIES may their susceptibility to predispose them to infections [3].

Manifestations of the syndrome may occur within the first few days of the infant's life, usually not later than at the age of 18-20 months [4]. The AD HIES is characterized by a triad of symptoms and signs, i.e., recurrent skin abscesses due to Staphylococcus aureus, recurrent pneumonias with pneumatoceles, atopic-like eczema. Blood serum shows an increased IgE titre and specific IgEs against inhaled, bacterial, fungal and food allergens, usually accom- 
panied by an impaired neutrophil function (chemotaxis) and eosinophilia [4].

Respiratory infections are most frequently caused by Staphylococcus aureus, less frequently by Haemophilus influenzae or Streptococcus pneumoniae; however, mucodermal candidiases found in $83 \%$ of patients, are due to Candida albicans $[2,4,7]$.

Patients with HIES may develop the so-called cold staphylococcal abscesses, frequently on the face. They occur in infancy and are sporadic; their presence is not a necessary condition to diagnose the disorder [2].

Most patients with hyper IgE syndrome develop asymmetricy and coarse facial features, deep-set eyes with orbital hypertelorism, a prominent forehead, wide nasal ala, a wide nasal root, a thick lower lip [2, 8, 9]. They are also found to have skeletal abnormalities: scoliosis, articular hyperflexibility, susceptibility to pathological fractures, osteopenia, and osteoporosis without clear evidence of impaired calcium-phosphate metabolism $[2,5,8]$.

The HIES patients are more predisposed to having autoimmune and neoplastic diseases (non-granulating lymphoma and Hodgkin disease) [2, 4, 9-12].

Physical examination of the oral cavity revealed predisposition to mucosal lesions, i.e., chronic candidiasis, hyperkeratosis and tongue lesions such as fissures [2, 13]. Dentition showed an abnormal composition of mineralized dental tissue, i.e., enamel hypoplasia and dentin defect. In $72 \%$ patients over the age of eight years, the findings include retained teeth, persistent deciduous teeth (two rows), supernumerary teeth [8, 13-15]. Skeletal abnormalities, pathological fractures, dental abnormalities and characteristic facial features are typical of the dominant inheritance in HIES $[2,8,13]$.

The aim of the present study was an attempt to establish oral phenotypic features in the autosomal dominant HIES with regard to a modifying effect of environmental factors.

\section{Material and methods}

The study included four patients with autosomal dominant hyper-IgE syndrome (13.5-29 years) followed up regularly in Immune Diseases Ward, Department of Gastroenterology, Hepatology and Immunology, and Department of Oral Pathology, The Children's Memorial Health Institute, Warsaw, Poland. Three patients were diagnosed with the STAT 3 gene mutation, patient No 3 was undergoing genetic testing (at the time of the study).

Clinical assessment was focused on the patients' general health status, documented in their medical records, dental examination, and radiology (pantomography). Physical examination included evaluation of the following:

- oral hygiene status: PL I [16];

- health status of paradontal tissues: gingival pocket depth (> $4 \mathrm{~mm}$ ), GI [16];
- health status of the oral mucosa (type and site of lesions) - examination focused on the presence, type and site of lesions in the oral mucosa based on the WHO Guide to Epidemiology and Diagnosis of Oral Mucosal Diseases [17];

- dental status:

- type of dentition (deciduous/permanent),

- number of missing teeth,

- number of teeth with active carious foci,

- number of teeth with enamel defects: a modified DDE (limited enamel opacities, diffuse opacities, and enamel hypoplasia) [18],

- number and type of permanent teeth with tooth wear: severity of tooth wear/TWI according to Smith and Knight (1984):

0 - no signs of enamel loss/no contour change in paracervical surface area

1 - visible loss of enamel surface/minimal change in enamel contour

2 - enamel loss with dentine exposure $<1 / 3$ dentine/dentine loss $<1 \mathrm{~mm}$

3 - enamel loss with dentine exposure $>1 / 2$ dentine/dentine loss $<1-2 \mathrm{~mm}$ from pulp with no exposure of pulp or secondary dentine

4 - total enamel loss with exposure of pulp or secondary dentine thickness $>2 \mathrm{~mm}[9,20]$.

Clinical examination was completed, according to medical indications, based on accessory investigations, i.e., pantomography, and mycology. Sample material for mycology was obtained by a direct smear from the buccal and lingual mucosa. The clinical material was quantitatively cultured on the Sabouraud solid medium. The culture was incubated at a temperature of $37^{\circ} \mathrm{C}$. The fungal species were identified using the ID $32^{\circ} \mathrm{C}$ test (bioMerieux) to assess their biochemical properties [21].

\section{Results}

\section{Patients' general health condition/status}

Patients' characteristics, including their age, gender, and medical history, based upon the latest HIES diagnostic guidelines, are presented in Table 1 [6]. All patients had developed general manifestations typical of the AD HIES; for which they had received several courses of a long-term antibiotic therapy. They also had iron deficiency anemia $(n=2)$, bronchial asthma $(n=1)$, digestive disorders: gastritis $(n=1)$. On the examination day, patient No 2 was noted to have aggravated skin problems (severe pruritus, scratched papules covered with eschar), patient No 4 had a submucosal abscess at area of teeth 04 and 05 . All the subjects had been treated with antibacterial and antimycotic agents; three patients, with agents for their digestive disorders (abdominal complaints following a long-term bactrim therapy), and iron preparations, one subject used anti-asthmatic inhalants (Table 1). 
Table 1. Patients with hyper IgE according to age, sex, general health status, and pharmacological treatment

\begin{tabular}{|c|c|c|c|c|}
\hline & \multicolumn{4}{|c|}{ Patient } \\
\hline & No 1 & No 2 & No 3 & No 4 \\
\hline Age (years) & 13.5 & 29 & 18.5 & 20 \\
\hline Sex/Gender & F & $\mathrm{F}$ & M & M \\
\hline \multicolumn{5}{|l|}{ Medical history } \\
\hline skin lesions abscesses & + & + & + & + \\
\hline chronic eczema & + & $+($ severe $)$ & + & + \\
\hline mucodermal candidiasis, & + & + & + & + \\
\hline organ abscess & + & - & - & + \\
\hline $\begin{array}{l}\text { recurrent respiratory or/ } \\
\text { and urinary infections }\end{array}$ & + & + & + & + \\
\hline sinusitis, otitis & + & + & - & - \\
\hline skeletal abnormalities & $\begin{array}{c}\text { scoliosis, } \\
\text { pathological fractures }\end{array}$ & scoliosis & pathological fractures & pathological fractures \\
\hline facial dysmorphia & + & + & + & + \\
\hline other & iron deficiency anemia & $\begin{array}{c}\text { iron deficiency anemia } \\
\text { bronchial asthma, } \\
\text { gastritis }\end{array}$ & gastrointestinal disorders & $\begin{array}{l}\text { gastrointestinal disorders } \\
\text { (condition following } \\
\text { hepatic abscess) }\end{array}$ \\
\hline $\begin{array}{l}\text { Pharmaceutical agents taken } \\
\text { on examination day }\end{array}$ & bactrim, orungal & $\begin{array}{l}\text { bactrim, ketokonazole, } \\
\text { flixotide, helicid, } \\
\text { sorbifer durules }\end{array}$ & $\begin{array}{l}\text { bactrim, } \\
\text { brungal, banigast }\end{array}$ & $\begin{array}{l}\text { biseptol, augmentin, } \\
\text { metronidazole diflukan, } \\
\text { ketokonazole, ranitidine }\end{array}$ \\
\hline
\end{tabular}

\section{Oral health status}

Oral mucosal lesions and dental abnormalities in patients with AD HIES are summarized in Table 2.

\section{The oral hygiene and health status of the gingiva and mucous membrane}

All the subjects had dental plague deposits (PLI: 1.662.58 ), mild or moderate gingivitis (GI: 0.83-2.00). Three patients had inflammatory erythema on the marginal gingiva. In one patient, it also involved the attached gingiva and the mucosa of the remaining oral regions. There were no gingival pockets $\geq 4 \mathrm{~mm}$.

All the patients were found to have white hyperkeratotic lesions in the mucosa of the cheeks, alveolar processes, palate, tongue, and retromolar regions. In both women, the oral mucosa was pale, particularly in the palate (iron deficiency anemia). Circumoral vitiligo was noted in one patient. Three patients had angular cheilitis and candidosis (Fig. 1). Mycology showed a high titre of Candida albicans $\left(>10^{3} \mathrm{CFU} / \mathrm{ml}\right.$ ) in all our patients, despite administration of antimycotic treatment. Two subjects had fibrosis in the hard palate. One person had ulceration on the lateral lingual margin, and one had a post-ulcerative scar. In two patients were observed changes on the tongue: deep median sulcus or grooves on dorsal surface with papillary atrophy. There were favourable environmental factors contributing to mucosal lesions in all the subjects (Table 1). A significant effect might have been exerted by iron deficiency anemia, digestive disorders and pharmacological agents.

\section{Dental health status}

All patients presented with dental caries and pathological attrition (max. values TW1 - 2), two - enamel hypoplasia of permanent dentition. Persistent deciduous teeth were found in two patients; in three subjects, permanent teeth were absent (a radiogram showed retained teeth, an absent bud of tooth 24) (Fig. 2). In one patient, teeth 83 and 43 were found to be in two rows.

\section{Radiology}

Radiology revealed absence of the dental bud of tooth 24 (patient No 1), retained teeth with well formed roots (patients No 1, 2, 4), an abnormal bone structure, including an irregular border of alveolar processes (all subjects), osteosclerotic lesions (patient No 1) (Fig. 2), osteolytic foci in a root area (patient No 4). It is worth noting that reduced bone density foci were also present in the root region of non-carious teeth with preserved vital pulp. 
Table 2. Lesions in the oral mucosa and dental abnormalities in patients with AD HIES

\begin{tabular}{|c|c|c|c|c|}
\hline \multicolumn{5}{|c|}{ Patient } \\
\hline & No 1 & No 2 & No 3 & No 4 \\
\hline Pl I & 2.33 & 2.58 & 2.50 & 1.66 \\
\hline GI & 0.83 & 1.66 & 1.50 & 2.00 \\
\hline Oral mucosa & $\begin{array}{c}\text { pallor } \\
\text { atrophic candidiasis; } \\
\text { angular cheilitis; } \\
\text { erosions and white } \\
\text { lichenoid lesions } \\
\text { on the buccal mucosa; } \\
\text { black tongue; } \\
\text { high palate }\end{array}$ & $\begin{array}{c}\text { pallor } \\
\text { pseudomembanous } \\
\text { candidiasis; } \\
\text { left angular cheilitis; } \\
\text { white lichenoid } \\
\text { lesions on the buccal } \\
\text { and alveolar processes } \\
\text { mucosa; } \\
\text { post-ulcerative scar } \\
\text { on the tongue; } \\
\text { high palate }\end{array}$ & $\begin{array}{l}\text { right angular eschar, } \\
\text { circumoral vitiligo } \\
\text { on the lips; } \\
\text { erosions and white } \\
\text { lichenoid lesions } \\
\text { on the buccal and } \\
\text { alveolar processes mucosa; } \\
\text { ulceration, hyperkeratotic } \\
\text { with lesions, } \\
\text { deep median sulcus, } \\
\text { with a papillary atrophy } \\
\text { in anterior part of tongue; } \\
\text { high palate with } \\
\text { irregular fibromatoses }\end{array}$ & $\begin{array}{l}\text { pseudomembanous } \\
\text { candidiasis, angular cheilitis, } \\
\text { angular hyperkeratosis, } \\
\text { mucosal erythema } \\
\text { and white lichenoid lesions } \\
\text { (lids, cheeks), grooves } \\
\text { on dorsal surface } \\
\text { papillary atrophy in anterior } \\
\text { part of tongue; } \\
\text { high palate with } \\
\text { erythema and fibromatoses } \\
\text { surrounded by grooves }\end{array}$ \\
\hline \multicolumn{5}{|l|}{ Teeth } \\
\hline Dental caries & $\begin{array}{c}55,53,63,65,73,74 \\
83,84,26,36,46\end{array}$ & $11,21,25,36$ & $36,44,45,46$ & $\begin{array}{c}53,63,64,16,36 \\
35,46,47\end{array}$ \\
\hline $\begin{array}{l}\text { Tooth wear } \\
\text { (TWI: min. - mas }\end{array}$ & $\begin{array}{l}\text { attrition; } 16,26,36,46 \\
\text { x.) (TWI: } 1-2)\end{array}$ & $\begin{array}{c}\text { 16/2/ } 11,13,21,23,26 \\
36,32,31,42,41,46 \\
\text { (TWI: } 1-2)\end{array}$ & $\begin{array}{c}\text { attrition; } 13,12,11,21,22, \\
31,32,33,41,42,43 \\
\text { (TWI: 1-2) } \\
\text { Rotation 43; } \\
\text { abfraction: } 31 \text { (TWI -1); } \\
\text { Crown fracture } 21 \\
\text { Class I/Ellis }\end{array}$ & $\begin{array}{c}\text { attrition; } 12,11,21,22, \\
\text { 31, } 3241,42,46 \\
\text { (TWI: } 1-2)\end{array}$ \\
\hline Enamel defects & - & $\begin{array}{c}\text { Enamel hypoplasia } \\
34,35,44\end{array}$ & $\begin{array}{c}\text { Enamel hypoplasia } \\
13 \text { and } 23\end{array}$ & - \\
\hline $\begin{array}{l}\text { Persistent } \\
\text { deciduous teeth }\end{array}$ & $\begin{array}{l}55,53,63,65 \\
74,73,83,84\end{array}$ & - & - & $53,64,65$ (root), 83 \\
\hline $\begin{array}{l}\text { Retained } \\
\text { permanent } \\
\text { teeth }\end{array}$ & $\begin{array}{c}17,15,13,23,25 \\
7,37,35,34,33 \text { (rotation), } \\
43 \text { (rotation), } 44,45,47\end{array}$ & $\begin{array}{c}24 \text { (history showed } \\
\text { a double row of teeth in } \\
\text { premolar region) }\end{array}$ & - & $13,24,25$ \\
\hline Hypodontia & 24 & - & - & - \\
\hline Radiogram & $\begin{array}{l}\text { osteosclerotic foci, } \\
\text { ones distal to retained } 37 \text {; } \\
\text { irregular bone border } \\
\text { of alveolar processes with } \\
\text { vertical atrophy in area of } \\
\qquad 12 \text { and } 22\end{array}$ & - & $\begin{array}{c}\text { osteolytic lesions in area } \\
\text { of tooth root } 14 \text { (caries-free); } \\
\text { irregular bone border } \\
\text { of alveolar processes with } \\
\text { vertical atrophy in area } \\
\text { of } 23 \text { and } 37\end{array}$ & $\begin{array}{l}\text { osteolytic lesions in area } \\
\text { of tooth roots } 21,32,31 \text {, } \\
41,42 \text { (caries-free) } \\
\text { and tooth } 36 \text { with } \\
\text { gangrenous pulp necrosis; } \\
\text { irregular bone border } \\
\text { of alveolar processes }\end{array}$ \\
\hline
\end{tabular}

\section{Discussion}

Hyper IgE syndrome is a multisystem condition associated with a dysfunction of the immune system, in which clinical manifestations affect the connective tissue and the skeletal system [8, 22]. Oral lesions in patients with HIES involve both the mucous membrane and dentition, and represent one of the features characteristic of the HIES inher- ited in an autosomal dominant pattern. The etiology of the changes in oral mucosal in patients with AD HIES has not been fully explained. The role of the STAT3 gene mutation in the etiology of palatin fibrous lesions also appears to be of significance. The gene plays its role in regulating the key cytokines (IL-6, IL-10, IL-17, IL-21, IL-22, IL-23) and Th17 deficit. 


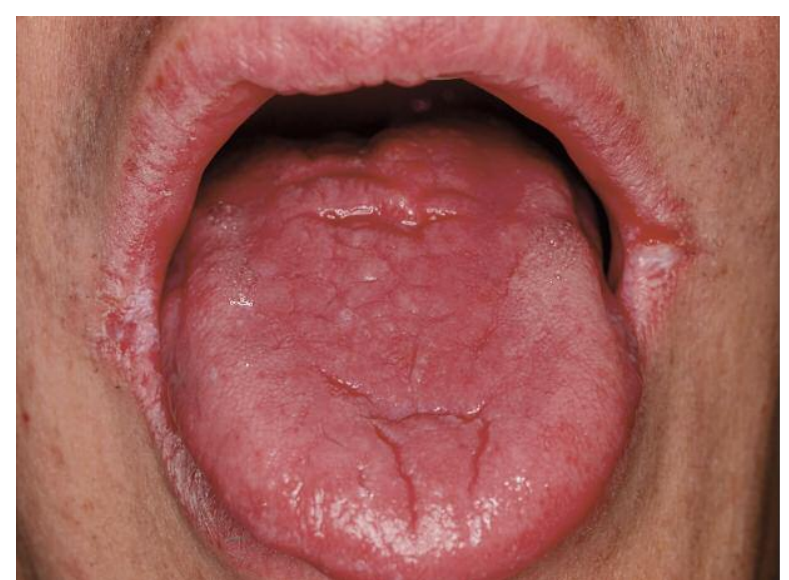

Fig. 1. Oral lesions in a patient with HIES - tongue fissures, angular cheilitis and angular hyperkeratosis

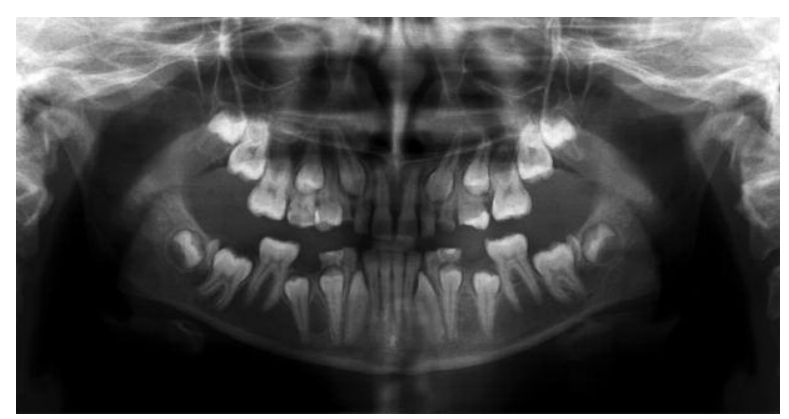

Fig. 2. The pantogram of a 13.5 year-old patient with HIES: retained teeth $17,15,13,23,25,27,37,35,34,33,43,44,45$, 47 , an absent tooth 24 , persistent deciduous teeth $55,53,63$, $65,74,73,83,84$, osteosclerotic foci distal to retained teeth 37 , irregular bone margins of alveolar processes with a vertical atrophy in the area of teeth 12 and 22

Dysfunction of the STAT 3 gene can lead to candidosis and epidermal hyperplasia and keratosis [23]. Frequent infections with Candida spp. in persons with HIES have been confirmed in reports by other authors. They found that $83 \%$ of their patients had concomitant chronic mycoses of the skin and mucous membranes caused by infection with Candida albicans and other fungal strains $[2,8,15]$. The high risk of candidiosis is correlated with downstream of the Th17 and probably with reduced expression of certain AMPs with antifungal activity, namely $\beta$-defensins and histatins [24].

The palatine fibrous lesions, as reported in patients with HIES, may be caused by disorders associated with IL-6 (induced fibroblast proliferation and collagen production).

In contrast to other authors, we did not find rhomboid tongue in any of our patients [15]. There were, however, other lesions, i.e., tongue fissures, atrophied foliate papillae, ulceration, scars and a black tongue. In the etiology of these abnormalities, researchers should also consider the impact of environmental factors, e.g., iron deficiency anemia, a long-term antibiotic therapy, administration of antiasthmatic inhalants, digestive diseases and disorders. Patients with hyper IgE syndrome may develop abnormal absorption from the digestive tract. The diagnosis also included eosinophilic gastroenteritis, hypersensitivity to food allergens and gastrointestinal infections, i.e., chronic candidiasis. Other authors also reported episodes of chronic diarrhea [25], gastrointestinal bleeding [26], and dysphagia caused by diverticula and esophageal stenosis [27]. A harmful effect is also due to a long-term antibiotic treatment, which, by acting on the intestinal bacterial flora, may inhibit vitamin synthesis. All those factors contribute to persistent fungal infections and induce manifestations typical of iron or vitamin deficiencies, e.g. paleness of the oral mucosa, atrophy of the lingual papillae, tongue fissures and slits, and angular cheilitis [28-30]. An unfavourable effect on the oral mucosa and dental tissue is also produced by a steroid anti-asthmatic agent used by a patient with bronchial asthma. Administration of steroid inhalants may be accompanied by e.g., irritation, hyperemia and thinning of the oral mucosa, submucosal petechiae, pruritus and oral pain, dysphagia. Those agents also contribute to fungal proliferation, and mechanical injuries [31].

It is considered that the phenotypic feature of AD HIES includes disorders in the eruption of permanent teeth and resorption of the deciduous teeth $[2,6,8]$. The STAT 3 gene may also play a role in odontogenesis. As it is generally known, the process depends on a normal mutual relationship between the ectodermal oral epithelium and the mesynchymal tissue, controlled, at the molecular level, by a range of regulators coded by a multiplicity of genes. Odontogenic dental defects are usually caused by mutations in the genes coding the above regulators, i.e. signalling particles and transcription factors. They may occur as single defects, or in combination with defects in other tissues or organs, as one of the features of the genetic syndrome. Impaired epithelial development resulting from the STAT3 gene mutation may also play a role in the etiology of developmental dental defects. In our reported cases we noted enamel hypoplasia, an absent bud of a permanent tooth, abnormal eruption of permanent dentition, and delayed root resorption of deciduous teeth.

Results of our observation of the presence of persistent deciduous teeth and retained teeth are consistent with those reported by other authors. It has been found that, in $75 \%$ of patients over seven years of age, root resorption of deciduous teeth is abnormal $[13,14]$. The researchers emphasize the fact that eruption of the permanent first and second molar teeth occurred at the appropriate age, which is indicative rather of a root resorption defect in the deciduous teeth, than of the tooth eruption process itself $[13,14]$.

Nevertheless, our assessment of a thirteen and a halfyear old girl showed an inhibited eruption process of permanent second molar teeth and a premolar tooth despite an 
absent equivalent of a deciduous tooth, which renders the theory invalid.

Moreover, a frequent finding is the presence of two rows of teeth, deciduous teeth with inhibited root resorption, and their erupted permanent equivalents. Some authors suggested the presence of a common factor responsible for both abnormal root resorption of deciduous teeth, and increased susceptibility to respiratory infections, as well as predisposition to pneumatocele formation in patients with AD HIES [13].

It seems, however, that abnormal eruption of the permanent, and resorption of the deciduous teeth should rather be associated with an abnormal bone tissue found in patients with the AD HIES. Over half of them had recurrent pathological fractures of the long bones due to minor injuries; fractures to the ribs and vertebral column were less frequent $[4,20]$. Over $60 \%$ of the patients develop scoliosis and articular hyperflexibility is also frequent $[1,8]$. The study by Duplomb et al. showed that inhibition of the STAT3 gene may switch off the mechanism of osteoclastogenesis dependent on RANKL [32]. However, a decreased level of IL-10 (osteoclast inhibitor) and an increase in TNF- $\alpha$ (osteoclast activator) may be responsible for bone resorption in patients with HIES [33]. In our reported cases, the abnormalities, both osteolytic and osteosclerotic, were found in maxillary bones. All the patients had developed skeletal disorders (scoliosis, pathological fractures).

Tooth eruption in patients with HIES is arrested at the intraosseous stage. At this eruption stage, bone resorption and formation on the opposite sides of the dental follicle, represent an important element. Inhibited osteoclastogenesis may arrest the eruption. Numerous factors play the role of eruption regulators at the intraosseous stage [34, 35]. Apart from RANK/RANKL (receptor activator of nuclear factor-kappa B/RANK Ligand), OPG (osteoprotefrin), and M-CSF (a macrophage colony-stimulating factor), also cytokines TNF- $\alpha$, IL-1 $\alpha$, IL-6, IL-11 and IL-17, exert their impact upon osteoclast differentiation and activation. A correlation has been found between a lack of activation of nuclear factor kappa B (RANK) and arrested tooth eruption [36]. RANK/RANKL is also a regulator of physiological root resorption in deciduous teeth, which is regulated by odontoclasts. The mechanisms of molecular control of odontoclasts has not been fully explained. However, it has been shown that the RANK receptor is expressed by odontoclasts, and RANKL, by odontoblasts, pulp and periodontal ligament [37-39].

No reports were published by other authors on dental lesions such as tooth wear, in patients with HIES. Three patients assessed at our Centre were diagnosed with tooth wear and injuries to the buccal mucosa in the occlusion line, ulceration, and ulcer scars on the lateral tongue margin, which were consistent with bruxism. Self-injuries to the oral mucosa and teeth are frequently associated with emotional and neurological disorders [40-42]. Clinical neurological manifestations in patients with HIES were reported as result- ing from vascular lesions in the CNS [43]. Brain MRI performed in 50 patients with HIES by Freeman et al. confirmed the presence of hyperintensities, mainly in the white matter. They occurred in adult subjects more frequently $(81 \%)$ than in children $(47 \%<18$ years of age). The youngest patient with focal hyperintensities was four years old. Clinical sequalae of the disorders are still not evident [43]. Although it is not plausible to exclude their significance in the etiopathology of bruxism, we suppose that bruxism and oral mucosal injuries are the effect of severe pruritus associated with the presence of eczema. Pruritus may be caused by an intradermal release of histamine from mast cells, associated with a high serum IgE titre. Bruxism is also most probably due to malocclusion and stress as well as emotional disorders accompanying the chronic disease and frequent hospital admissions.

Association between bruxism, allergic diseases and psychological problems has been well established [42-46]. It is indicated to perform investigations to determine the incidence of self-injuries in patients with HIES, and also identify the causative factors, since frequent oral mucosal injuries, in view of a permanent Candida spp. presence, are at risk of fungemia. It is also vital to assess carefully the etiopathogenesis of osseous lesions and impaired eruption of permanent teeth as well as root resorption of deciduous teeth. Possible bone remodelling provides a basis for orthodontic treatment, which, in this group of patients is of particular significance, also as a prophylactic component in tooth wear, dental caries, and mechanical injuries to the oral mucosal membrane.

\section{Conclusions}

In spite of the identified, genetic causes of HIES, the pathology of oral lesions in patients with the syndrome, still requires further explanation. The present knowledge allows associating the oral mucosal lesions, i.e. fungal infections, hyperkeratosis and fibroplasias, with the STAT3 gene mutation. It is also plausible to consider its role in disorders of odontogenesis, particularly in inhibiting the eruption of permanent teeth, and the root resorption of deciduous teeth. Oral lesions in AD HIES are, however, characterized by a phenotypic variability, which may be due to additional factors (epigenetic and environmental), e.g.: pruritus, infection, frequent administration and long-term courses of antibiotics, anti-asthmatic inhalants, iron deficiency anemia, digestive diseases and disorders, or emotional factors.

There are no prior publications or submissions with any overlapping information, including studies and patients.

The manuscript has not been and will not be submitted to any other journal while it is under consideration by The Journal of Pediatrics. 
There are any potential conflict of interest, real or perceived; this includes a description of the role of the study sponsor(s), if any, in: (1) study design; (2) the collection, analysis, and interpretation of data; (3) the writing of the report; and (4) the decision to submit the paper for publication because there are any sponsor(s).

The first draft of the manuscript wrote authors together and any honorarium, grant, or other form of payment was given to anyone to produce the manuscript.

Each author listed on the manuscript has seen and approved the submission of this version of the manuscript and takes full responsibility for the manuscript.

\section{References}

1. Davis SD, Schaller J, Wedgwood RJ (1966): Job's syndrome: Recurrent, „cold” staphylococcal abscesses. Lancet 1: 10131015.

2. Heropolitańska-Pliszka E, Pietrucha B, Mikołuć B i wsp. (2009): Zespół hiper-IgE z mutacją w genie STAT3 - opis przypadku i przegląd piśmiennictwa. Med Wieku Rozwoj 13: 19-24.

3. Minegishi Y, Karasuyama H (2008): Genetic origins of hyperIgE syndrome. Curr Allergy and Asthma Reports 8: 386-391.

4. Szyguła-Kotala E, Sąda-Cieślarz M, Buszman Z (2006): Wielonarządowa manifestacja zakażenia gronkowcem złocistym u dziecka z zespołem hiperIgE. Alerg Astma Immun 11: 1-10.

5. Nowicka U, Wiatr E, Kupis W (2007): Pneumatocele w trakcie długotrwałej obserwacji chorego na zespół hiper IgE (zespół Hioba). Pneumonol Alergol Pol 75: 200-207.

6. Woellner C, Gertz M, Schaffer A, et al. (2010): Mutations in STAT3 and diagnostic guidelines for hyper-IgE syndrome. J Allergy Clin Immunol 125: 424-432.

7. DeWitt CA, Bishop AB, Buescher LS, Stone SP (2006): Hyperimmunoglobulin $\mathrm{E}$ syndrome: two cases and a review of the literature. J Am Acad Dermatol 54: 855-865.

8. Dmeńska H (2008): Zespół Hiper-IgE. Część II. Postać dziedziczona autosomalnie dominująco (AD-HIES). Alergologia Info 3: 157-162.

9. Garraud O, Mollis SN, Holland SM, et al. (1999): Regulation of immunoglobulin production in hiper IgE (Job's) syndrome. J Allergy Clin Immunol 103: 333-340.

10. Lin SJ, Huang JL, Hsieh KH (1998): Hodgkin's disease in child with hyperimmunoglobulin E syndrome. Pediatr Hematol Oncol 15: 451-454.

11. Chang SE, Huh J, Choi JH, et al. (2002): A case of hyper-IgE syndrome complicated by cutaneous, nodal, and liver peripheral T cell lymphomas. J Dermatol 29: 320-322.

12. Kashef MA, Kashef S, Handjani F, Karimi M (2006): Hodgkin lymphoma developing in a 4.5-year-old girl with hyper-IgE syndrome. Pediatr Hematol Oncol 23: 59-63.

13. Karimi M (2006): Hodgkin lymphoma developing in a 4.5year-old girl with hyper-IgE syndrome. Pediatr Hematol Oncol 23: 59-63.

14. Grimbacher B, Holland SM, Gallin JI, et al. (1999): Hyper-IgE syndrome with recurrent infections-an autosomal dominant multisystem disorder. N Engl J Med 1999; 340: 692-702.

15. O'Connell AC, Puck JM, Grimbacher B, et al. (2000): Delayed eruption of permanent teeth in hyperimmunoglobulinemia $\mathrm{E}$ recurrent infection syndrome. Oral Surg Oral Med Oral Pathol Oral Radiol Endod 89: 177-185.
16. Grimbacher B, Holland SM, Puck JM (2005): Hyper-IgE syndromes. Immunol Rev 203: 244-250.

17. Löe H (1967): The Gingival Index, the Plaque Index and the Retention Index Systems. J Periodontal 38: 610-616.

18. Kramer IR, Pindborg JJ, Bezroukov V, Infirri JS (1980): Guide to epidemiology and diagnosis of oral mucosal diseases and conditions. World Health Organization. Community Dent Oral Epidemiol 8: 1-26.

19. Clarkson J, O’Mullane D (1989): A modified DDE index for use in epidemiological studies of enamel defects. J Dent Res 68: 445-450.

20. Smith BG, Knight JK (1984): A comparison of patterns of tooth wear with aetiological factors. Br Dent J 157: 16-19.

21. Smith BG, Knight JK (1984): An index for measuring the wear of teeth. Br Dent J 156: 435-438.

22. Samaranayake LP, MacFarlane TW, Lamey PJ, Ferguson MM (1986): A comparison of oral rinse and imprint sampling techniques for the detection of yeast, coliform and Staphylococcus aureus carriage in the oral cavity. J Oral Pat Med 15: 386-388.

23. Erlewyn-Lajeunesse MD (2000): Hyperimmunoglobulin-E syndrome with recurrent infection: a review of current opinion and treatment. Pediatr Allergy Immunol 11: 133-141.

24. Heimall J, Freeman A, Holland SM (2010): Pathogenesis of hyper IgE syndrome. Clin Rev Allergy Immunol 38: 32-38.

25. Conti HR, Baker O, Freeman AF, et al. (2011): New mechanism of oral immunity to mucosal candidiasis in hyper-IgE syndrome. Mucosal Immunol 4: 448-455.

26. Sriram P, Venkatesh C, Risbud T, et al. (2010): Chronic diarrhea with Hyper Immunoglobulin E syndrome. Curr Pediatr Res 14: 15-17.

27. Götzberger M, Schlesinger A, Dauer M (2004): A rare cause of gastrointestinal bleeding in a patient with hyper-IgE syndrome. Gut 53: 1430-1436.

28. Freeman AF, Holland SM (2009): Clinical manifestations, etiology, and pathogenesis of the hyper-IgE syndromes. Pediatr Res 65: 32-37.

29. Pierro VS, Maia LC, Primo LG, Soares FD (2004): Case report: the importance of oral manifestations in diagnosing iron deficiency in childhood. Eur J Paediatr Dent 5: 115-118.

30. Rosińska-Więckowicz A, Misterska M, Bartoszak L, Żaba R (2011): Cheilitis - case study and literature review. Postep Derm Alergol 28: 231-239.

31. Chi AC, Neville BW, Krayer JW, Gonsalves WC (2010): Oral manifestations of systemic disease. Am Fam Physician 82: 1381-1388.

32. Martyn M, Bachanek T (2006): Treated for bronchial asthma and the condition of oral cavity - critical overview. Dent Med Probl 43: 269-276.

33. Duplomb L, Baud'huin M, Charrier C, et al. (2008): Interleukin-6 inhibits receptor activator of nuclear factor kappaB ligand-induced osteoclastogenesis by diverting cells into the macrophage lineage: key role of Serine727 phosphorylation of signal transducer and activator of transcription 3. Endocrinology 149: 3688-3697.

34. Datta HK, Ng WF, Walker JA, et al. (2008): The cell biology of bone metabolism. J Clin Pathol 61: 577-587.

35. Wise GE, King GJ (2008): Mechanisms of tooth eruption and orthodontic tooth movement. J Dent Res 87: 414-434.

36. Suri L, Gagari E, Vastardis H. (2004): Delayed tooth eruption: Pathogenesis, diagnosis, and treatment. A literature review. Am J Orthod Dentofacial Orthop 126: 432-445.

37. Kong YY, Yoshida H, Sarosi I, et al. (1999): OPGL is a key regulator of osteoclastogenesis, lymphocyte development and lymph-node organogenesis. Nature 397: 315-323. 
38. Hasegawa T, Kikuiri T, Takeyama S, et al. (2002): Human periodontal ligament cells derived from deciduous teeth induce osteoclastogenesis in vitro. Tissue Cell 34: 44-51.

39. Lossdörfer S, Götz W, Jäger A (2002): Immunohistochemical localization of receptor activator of nuclear factor kappaB (RANK) and its ligand (RANKL) in human deciduous teeth. Calcif Tissue Int 71: 45-52.

40. Harokopakis-Hajishengallis E (2007): Physiologic root resorption in primary teeth: molecular and histological events. J Oral Science 49: 1-12.

41. Romero M, Vicente A, Bravo LA (2005): Prevention of habitual cheek biting: a case report. Spec Care Dentist 25: 214-216.

42. Medina AC, Sogbe R, Gómez-Rey AM, Mata M (2003): Factitial oral lesions in an autistic paediatric patient. International Int J Paediatr Dent 13: 130-137.

43. Olczak-Kowalczyk D, Witt A, Gozdowski D, Ginalska-Malinowska M (2011): Oral mucosa In children with Prader-Willi syndrome. J Oral Pathol Med 40: 778-784.

44. Freeman AF, Collura-Burke CJ, Patronas NJ, et al. (2007): Brain abnormalities in patients with hyperimmunoglobulin $\mathrm{E}$ syndrome. Pediatrics 119: e1121-1125.

45. Meyer B, Marks MD (1980): Bruxism in allergic children. Am J Orthod 77: 48-59.

46. Antonio AG, Da Silva Pierro VS, Maia LC (2006): Bruxism in children: a warning sign for psychological problems. J Can Dent Assoc 72: 155-160. 